\title{
A dynamic model to analyse the bio-technical and socio-economic interactions in dairy farming systems on the Réunion Island
}

\author{
Kamel LOUHICHI $^{\mathrm{a} *}$, Véronique ALARY ${ }^{\mathrm{b}}$, Patrice GRIMAUD ${ }^{\mathrm{b}}$ \\ a Institut Agronomique Méditerranéen de Montpellier, 3191 route de Mende, \\ BP 5056, 34093 Montpellier, France \\ b CIRAD-Emvt, Campus International de Baillarguet, TA 30/4, \\ 34398 Montpellier, France
}

(Received 24 March 2003; accepted 16 June 2004)

\begin{abstract}
This paper presents a framework that permits an integrated analysis of a complex livestock system in which biophysical, technical, socio-economic and policy components intervene. The main aims were to analyse the investment decisions and management strategy in the livestock system, and to simulate its future evolution under exogenous shocks (agricultural policies, technical opportunity). A multidisciplinary approach was used, based on a dynamic linear programming model that integrates technical and socio-economic constraints, policy making, technology choice, opportunities and farmer's objectives. This approach postulates that farmers make their decisions according to knowledge of the relation between production factors, the amount of output obtained and the level of unit costs of each production activity and future market prices. A technical matrix, containing a collection of relevant technical coefficients that describe the production functions (input-output coefficients), was built on the basis of observations of local farming systems. These coefficients and the opportunities offered to each farm type to produce goods subject to constraints are expressed in linear equations and are introduced in the model types. This modelling approach was used in the case of the dairy farming system on the Réunion Island. Applied to six dairy farm types, this approach showed the correct representation of the observed behaviour by the model, and the extreme sensitiveness of most farming incomes to agricultural policies and especially to public support. These models are currently operational and may be used to accompany decision-makers, especially dairy cooperative leaders, in their considerations on the management of farms.
\end{abstract}

interdisciplinary research / bio-technical and socio-economic interactions / dairy farming system / Réunion Island / dynamic mathematical programming / farm type model

Résumé - Application d'un modèle dynamique à l'analyse des interactions bio-techniques et socio-économiques dans les systèmes d'élevage laitiers à l'île de la Réunion. Ce papier propose un cadre d'analyse des systèmes d'élevage laitiers où des composantes biophysiques, techniques, socio-économiques et politiques interviennent fortement dans le processus décisionnel. Les principaux objectifs sont l'analyse des choix stratégiques et d'investissement dans ce système, et la simulation de leurs évolutions suite à des chocs exogènes (réforme des politiques agricoles, changements techniques). Une approche multidisciplinaire associant des connaissances en sciences

* Corresponding author: louhichi@iamm.fr 
économiques, physiologiques, zootechniques et agronomiques, est utilisée. Cette approche est basée sur la construction de modèles de programmation linéaire dynamique qui intègrent les contraintes bio-économiques, les divers choix techniques, les variables politiques et les objectifs des producteurs. Le cas spécifique des systèmes d'élevage laitiers à l'île de la Réunion est exposé comme un terrain d'application de cette approche. Appliquée à six exploitations-types, cette approche montre, d'une part, la bonne représentation, par les modèles, des modes de comportements des producteurs et, d'autre part, l'extrême sensibilité de la plupart des exploitations à la réforme de la politique agricole et spécialement aux systèmes d'aides et de prix. Ces modèles sont actuellement fonctionnels et peuvent être utilisés par les décideurs, notamment ceux de la coopérative laitière, comme un outil d'aide à la décision, pour les accompagner dans leurs réflexions sur la conduite future des exploitations agricoles.

recherche interdisciplinaire / interactions bio-techniques et socio-économiques / système d'élevage laitier / île de la Réunion / programmation mathématique dynamique / modèle de l'exploitation type

\section{INTRODUCTION}

The Réunion Island is a small island in the Indian Ocean. Its coastal area is dominated by sugarcane production, whereas the hillside central zone is used for cattle farming and some crops, such as geraniums. The dairy sector on the Réunion Island has experienced a rapid growth during the nineteensixties, due to institutional and organisational factors (cooperative implementation in 1962, dairy processing unit in 1972), the political involvement with the regional hillside development plan, and the social interest to develop milk supply and processing.

Currently, the cooperative includes approximately 150 dairy farms, which provide 20 million litres of milk. Since the nineteennineties, the cooperative has been confronted with two main questions: (i) How to increase milk production in a densely populated territory? (ii) What is the optimal farm size and livestock management to increase rural income while preserving natural resources? While considerable progress has been made in terms of animal performance and sanitary conditions, institutional and societal changes raise new questions such as: how can productivity be increased, ensuring the viability and future competitiveness offarms, while respecting the environment, under probably some agricultural policy reforms and modifications in the price structure?
The main purpose of this paper was to develop a bio-economical model ${ }^{1}$ that represents the complex interrelations between the bio-technical and socio-economical components that characterise different dairy production systems in the Réunion Island. Our objective was first to identify and to explain the determinants of these dairy farming systems, and secondly, to anticipate the evolution of these determinants under agricultural policy reforms and technical changes. A modelling approach was used that integrates technical and socio-economical constraints, policy making, technology and coefficient choice, opportunities and farmer's objectives.

\section{MATERIALS AND METHODS}

\subsection{Choice of the modelling approach: Linear Mathematical Programming}

Dairy farming, as well as other agricultural activities, is facing important changes coming from different sources that influence farmers' decisions, such as public policy change or agro-climate variations. In contrast to farming systems based only on annual crops or short cycle animal systems,

\footnotetext{
1 The bio-economic term used in this study does not mean linking of biophysical and economical models [12], but rather an economical model that integrates bio-technical functions and constraints.
} 
the functioning of dairy farming depends on complex interactions between past (e.g., improvement of fodder systems, restocking decisions) and present decisions whose effects are extended into the future. Anticipating these changes and evaluating them is critical and it is crucial to improve the decision-making processes both at the farm and sector level and to consider the consequences of environmental and policy measurements. Nevertheless, anticipation and exploration require an integrated approach of the farming system, and involves collaboration between distinct disciplines including economy, agronomy and animal science. The classical one-dimensional approaches such as economic cost benefit or econometric analysis are less effective, due to the multiplicity and to the non-monetarisation of many parameters affecting decisions in dairy farming systems.

In economic or agricultural economic sciences, several approaches have been developed to analyse interactions in farming systems. Most of these are based on the knowledge of the production functions and on the representation of the available set of techniques in a model. Production functions represent the different possible combinations of production factors that can be used to produce output. The interactions between inputs and outputs make their determination difficult in farming systems. In our study, we chose a linear mathematical programming (LMP) approach. LMP consists in solving problems of maximisation (or minimisation) of a linear mathematical function (the objective function), subordinated to a certain number of constraints, which are also linear $[4,10]$. The advantages of this approach are (i) its perfect correspondence with microeconomic theory based on the principle constrained optimisation; (ii) its simplicity and its ability for representing complex farming systems, in contrast with econometric models which rest on the building of a production function. The LMP limitations are (i) its inability to reproduce exactly reality and to represent the strategy of the group in case of the Farm Type Methodology [13], and (ii) the non-flexibility of its structure. Face to exogenous shocks, two assumptions can occur: no change at all, or a very large change in the farm's production behaviour and strategy [13, 16, 17, 22]. To circumvent some of these limitations, two extensions of linear programming have been developed. The first extension is based on the use of "Positive Mathematical Programming" (PMP) and "Symmetric Positive Equilibrium Problems" (SPEP), developed respectively by Howitt [18] and Paris and Howitt [23], in the aim to reproduce reality by the "dual" approach. A non-correspondence between model results and the current situation means that both technical constraints and cost (or yield) specification were not taken into account, and so they had to be included in the objective function via a nonlinear cost (or production) function $[3,6]$. The limits of these methods are the following: (i) the mixing of land, technical, agronomical, economical, and financial constraints in the cost functions is very complicated and (ii) the choice of the functional form and the construction of this cost function, with likely a quadratic specification, recall the same problems as econometric modelling.

The second extension is based on the addition of risk and uncertainty to the linear programming model [8]. This particularly concerns the risk for weather variability like the yields per hectare and uncertainty for the economical environment such as good prices, and/or direct payments [9]. Several risk methods within the LMP have been proposed including MOTAD, Target MOTAD, Esperance-Variance, and Safety first [1, 9, 19]. This approach has been applied to different livestock systems under various agroecological conditions and at different analysis levels (i.e., farm, region, country) [2bis, $5,9,11,20]$.

In our study, we chose the second extension in the aim to reproduce the farmer's observed behaviour (positive assumption) instead of advising them on the best way to use their resources (normative assumption). The quality of the technical, agronomical, 
and economic studies developed by animal scientists and grassland experts on the Réunion Island provides a wide range of technical coefficients and improves the calibration of these models $[2,7,14,15,26]$. The risk introduction in the model allowed calibrating the model for each farm type according to farmer risk aversion.

\subsection{Model specification: assumption and structure}

The model is based on dynamic linear mathematical programming, which incorporates the risk and uncertainty in three main parameters: yields, prices and direct payments. The dynamic specification assumes a multiannual and recursive model, the results of a year depending on those of the previous year. Modelling the interrelations between the different components of a farm system (i.e., livestock and cropping systems, labour competition, management and socio-economical strategy) is a novel aspect.

Applying this method requires to classify the farms in homogeneous groups in order to cover the diversity of dairy farming systems, and to build a model for each group thus representing the diversity of the area studied and to detect their adaptation behaviour to external conditions. The main criteria chosen to classify the population were structural (livestock, land, equipment), functional (feeding system, livestock management) and socio-economic (as the characteristics of the head of the farm, the family implication in the farm, the economic and financial ratios, the off farm activities). A previous analysis [2] revealed an important structuring of the dairy producers' population. It resulted in a differentiation of dairy farms into six farm types, according to a classification along two axes (Fig. 1): the first axis distinguished the degree and the rhythm of capitalisation (e.g., farm size) whereas the second axis made a differentiation according to the management of limiting resource.

The main components of the model type are detailed in Figure 2: (i) the objectives of the farmer that will define the objective function;

(ii) the technical coefficient matrix including, for each activity, the relation between production factors (inputs) used and goods obtained (outputs);

(iii) the financial, technical, economical, agronomical constraints;

(iv) the interrelations between the bio-technical and socio-economical systems.

\subsubsection{General structure of the model}

The general structure of the model can be formally represented as:

Maximise: Utility $=\sum_{\mathrm{ye}=\mathrm{t} 0}^{\mathrm{T}} \frac{\mathrm{C}_{\mathrm{ye}} \mathrm{X}_{\mathrm{ye}}-\phi \lambda_{\mathrm{t}}}{(1+\tau)^{\mathrm{ye}}}$.

Subject to: $\mathrm{AX}_{\mathrm{ye}} \leq \mathrm{B}_{\mathrm{ye}} ; \mathrm{B}_{\mathrm{ye}}=\mathrm{bX}_{\mathrm{ye}-1}$; $\mathrm{X}_{\mathrm{ye}} \geq 0$.

Where "Utility" is the objective function that has to be maximised, $\mathrm{C}_{\mathrm{ye}}$ the vector of expected income from production activities in the year (ye), $X_{y e}$ the vector of activities' level, $\Phi$ risk aversion coefficient according to the Target MOTAD method, $\lambda_{\text {ye }}$ the sum of negative deviations related to the income threshold (fixed for each farm type), $\mathrm{T}$ the planning horizon, $\tau$ the discount rate, $\mathrm{A}$ the matrix of technical coefficients, and $\mathrm{B}_{\mathrm{ye}}$ the vector of right-hand-side values [21].

The objective function supposes that the farmers make their decisions in order to maximise an expected utility in which expected disposable net income $\left(\mathrm{C}_{\mathrm{ye}} \mathrm{X}_{\mathrm{ye}}\right)$ and risk $\left(\lambda_{\text {ye }}\right)$ are explanatory variables. The optimisation of this function was fixed in a sequence of five years (2000-2004), which represent the planning horizon for the decision-making process, and which is similar to the expected life span of dairy cows. This function supposed that yield and price can fluctuate in a random way, and that farmers decide their farm management in order to avoid a catastrophic situation. Risk-taking is formulated under Tauer's hypothesis [25] that fixes a threshold of viability and takes into account different attitudes concerning risk-taking. Therefore, 


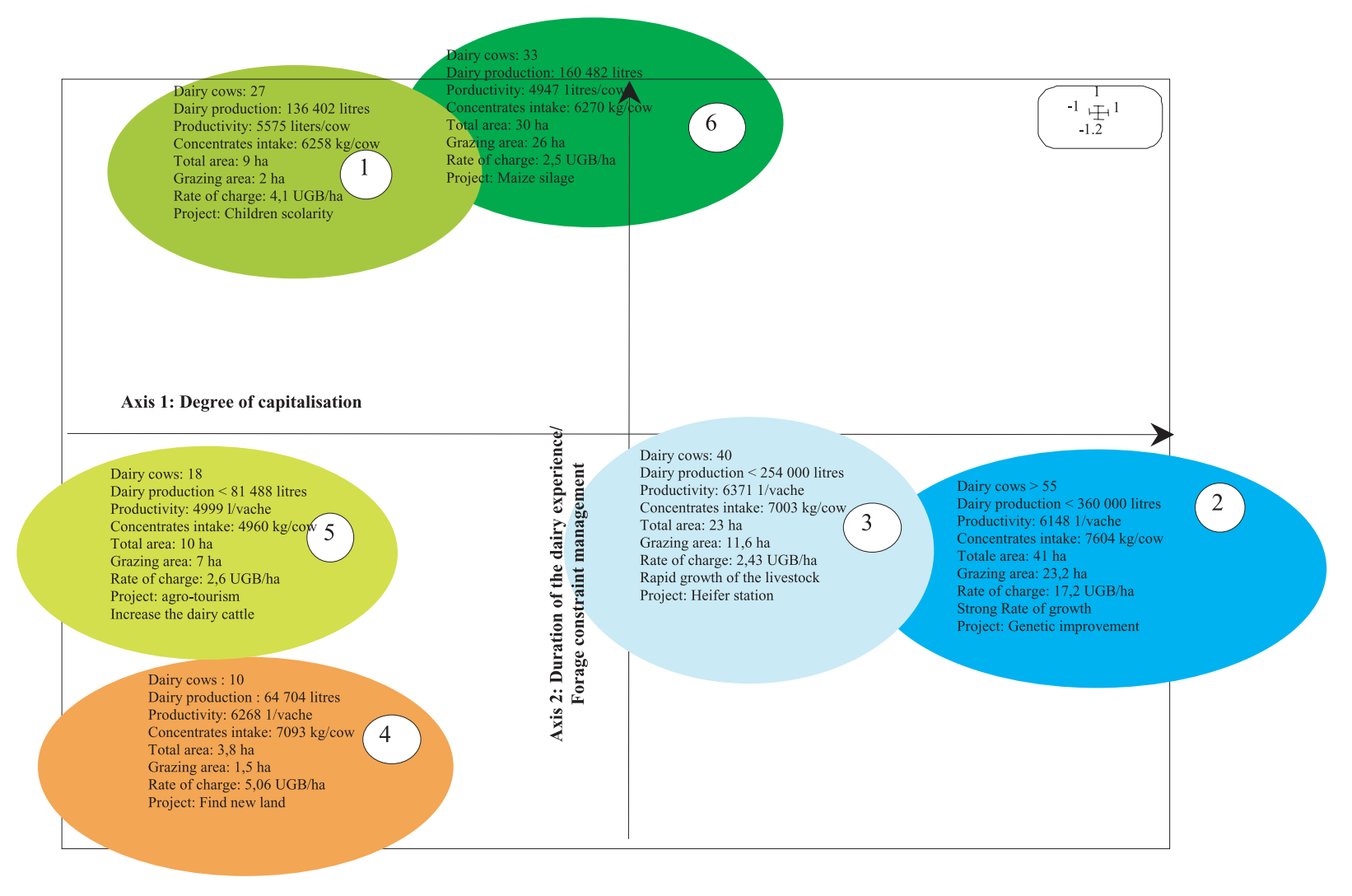

Figure 1. Typology of dairy farm and representation on the two first main factorial axes. 


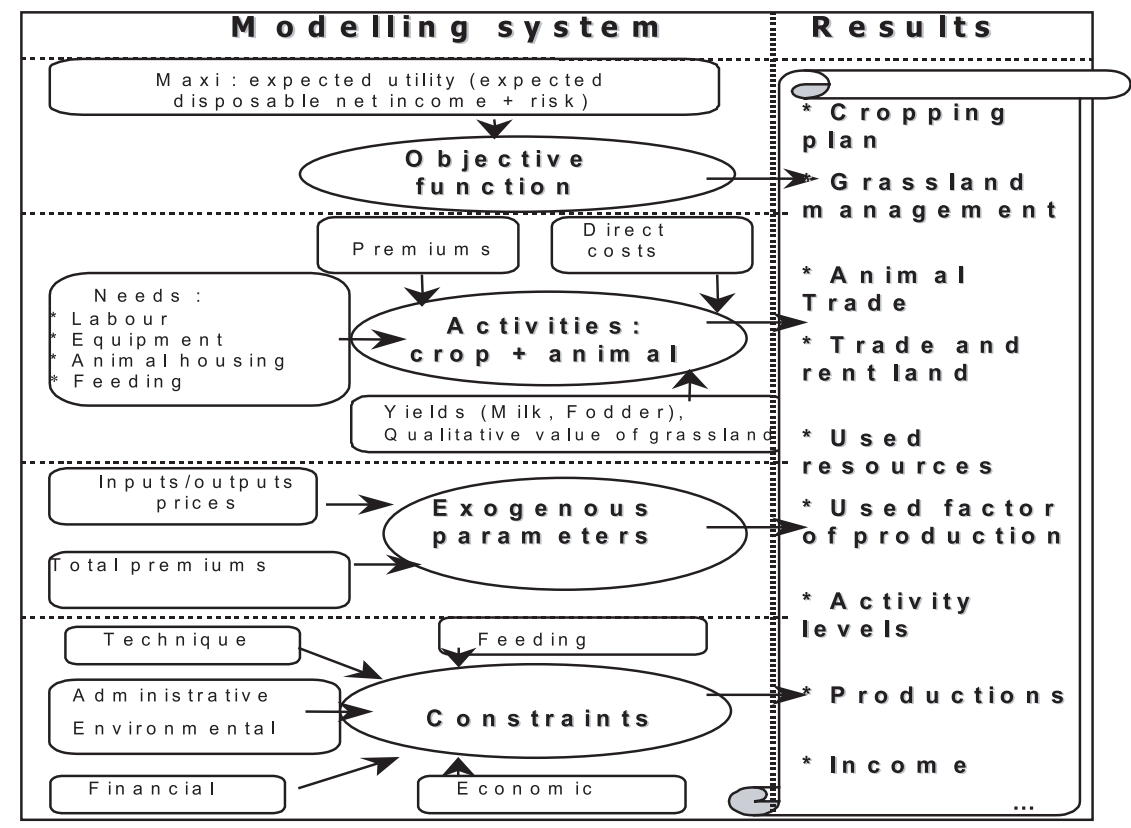

Figure 2. The main components of the modelling system.

farmers make their decisions in order to face different perturbations and ensure the viability and stability of their farm system.

The risk aversion coefficient $(\Phi)$ was exogenously specified. Its value was chosen with a reference to the fodder patterns and to the income levels observed in the basic situation (i.e., base year 2000) and remained unchanged over the time horizon of the model. Producer prices during each year were also taken as exogenously set. Land availability for fodder, animal and feed activity levels, financial flows, production, sales and used levels of each activity were determined endogenously. The model was subject to a number of explicit constraints (i.e., regarding land, technical and economic aspects, cashflows, policy, risk) and feeding restrictions. For ease of reference, activities and their specific sets are grouped in Table I. Fodder production activity was defined according to seven sets of characteristics, and animal production according to three sets.
The model distinguishes three types of decisions: seasonal decisions, annual decisions and long-term decisions:

- The seasonal decisions concern the supply of feed resources (e.g., concentrates or purchased feed) and the charges relative to the fodder system (e.g., fertiliser, seed) and to operational means (e.g., fuel, oil). These charges depend on the farm size (i.e., fodder area, animal stock, degree of mechanisation), grassland management and expected milk yield.

- The annual decisions concern mainly annual loans to compensate for seasonal cash flow variations.

- The long-term decisions concern investments, such as the purchase of equipment or farm buildings, animal husbandry, improvement of pastures, and purchase of breeding animals. These investments are covered with personal capital and long-term credit as methods of payment. 
Table I. Sets used to define production activities.

\begin{tabular}{|c|c|}
\hline Fodder production activity & Animal production activity \\
\hline $\begin{array}{l}\text { 1- Crop, fodder and grassland species (c): Pennisetum } \\
\text { clandestinum, Lolium perenne, Pennisetum purpureum, } \\
\text { Bromus fertilis, Chloris Gayana, etc.; } \\
\text { 2- Land operation development (ame): meadows fitted } \\
\text { for cutting and grazing meadows; } \\
\text { 3- Technique (T): grassland renovation (renewal) or no; } \\
\text { 4- Harvesting system (p): grazing, hay, silage, straw, } \\
\text { green, etc.; } \\
\text { 5- Number of cuttings and grazing during the season } \\
\text { (cp): cp1, cp2, cp3, cp4, cp5; } \\
\text { 6- Season (pc): summer (December to May), winter } \\
\text { (June to November); } \\
\text { 7- Localisation (f): P. Cafres, P. Palmistes, H. Ouest, } \\
\text { St Joseph. }\end{array}$ & $\begin{array}{l}\text { 1- Animal categories (tbov): young animal } \\
\text { (male and heifer Calves, bulls and heifers } \\
\text { (1, 1.5, 2, 2.5 years old), cow; } \\
\text { 2- Real genetic potential (gen): vl40 } \\
\text { (4000 litres per years), vl45, vl50, vl55, } \\
\text { vl60, vl65; } \\
\text { 3- Season (pc): summer (December to } \\
\text { May), winter (June to November). }\end{array}$ \\
\hline
\end{tabular}
Source: from the models.

\subsubsection{Writing the model equations ${ }^{2}$}

To be efficient, the model must take into account the particularities of dairy farm management on the Réunion Island, and must consider land management, animal performance, and herd demography. These biotechnical criteria have to be closely related to socio-economic constraints or to the decision process. This articulation focuses on the difficulty to analyse separately each different aspect of the whole farming system, and the interaction between biotechnical and socio-economic components must be included in the model. Therefore, the multiperiod model allows joining and analysing the articulation of farmers' decisions at short, medium, and long term.

\subsubsection{Land management and forage characteristics}

The nature of the pastures on the island varies with altitude and agro-climatic con-

\footnotetext{
2 A detailed description of the equations for the model, in mathematical form, is presented in Appendix 2. The model is written in Gams (General Algebraic Modeling System) language; full details are available from the authors.
}

ditions $[7,14]$. Temperate forages, such as ray grass (Lolium perenne), grow at an altitude of more than $1000 \mathrm{~m}$; although tropical grasses, such as chloris (Chloris gayana) and fodder sugarcane (Pennisetum purpureum), are dominant on the littoral. Only one tropical species, the kikuyu grass (Pennisetum clandestinum), covers a wide range of altitudes (from 800 to $1500 \mathrm{~m}$ asl). According to available mechanisation, fodder species, and location of the pastures, ten pasture management systems have been identified; forages can be either grazed or cut according to the farmers' decisions and the type of land improvement. The total land devoted to animal feeding also includes fallow land or rangeland.

Fodder quality during a season depends on the maturation of individual plant species, harvesting system and grassland location. Farmers practice between 1 and 3 cuts (up to 5 cuts for chloris), and maturation is estimated from the number of cuts during the season. Seasonal average data on forage quality (dry matter, energy and protein values) were obtained for pasture monitoring [14]. The range of these values was estimated with grassland experts and researchers in regard to the geographical situation of the grassland on the island. 
For each type of farm, the initial land endowment was specified. According to the pasture access, to the slope gradient and gravel density, the land was either described as "easy" (and could be renewed every season) or "difficult" (preventing mechanical harvesting). Grassland management (i.e., fertiliser, seeding practices, harvesting mode) depends on the number of forage cuttings or grazing, the cost of inputs and mechanisation, and the expected feedstock.

\subsubsection{Animal feeding}

The consumption of on-farm resources plus the purchased feed and commercial concentrates must cover the nutritional requirements of the herd. The qualitative value of the production depends on decisions concerning the harvesting system, fodder species, stage of maturation during the season and land improvement at the beginning of the season. Animal feeding on the island must take into consideration the use of sugarcane and its by-products (i.e., sugarcane cabbage, sugarcane straw and bagasse).

Herd nutritional requirements for maintenance were calculated from the average daily need per animal (defined by age and sex) and per day, plus $10 \%$ due to the harsh conditions [15]. Nutritional requirements for milk production depend on the genetic potential of the animals and milk productivity expectations. Six types of dairy cattle were assumed according to the average dairy production per year (from 4000 to 6500 litres per year per cow). Initially, each farmer was characterised by one level of dairy production that reflected the breed improvement and his feeding system. This dairy potential is determined thanks to the reproductive monitoring. During the horizon of planning, each farm type can decide to improve his dairy potential by investing in new dairy animals with a higher dairy potential. The nutritional requirements change for each dairy animal characterised by its dairy potential. In determining the nutritional supply and requirements, it was assumed that: (i) sugarcane cabbage cannot exceed $8 \%$ of dry matter intake; (ii) total sugarcane by-product consumption at the regional level cannot exceed the production on the mechanised sugarcane area in the island; (iii) commercial concentrate intake cannot exceed $70 \%$ of dry matter diet; (iv) total crude cellulose of the diet must exceed $18 \%$ of dry matter intake of the total diet; (v) molasses intake cannot exceed $1 \mathrm{~kg}$ per day per animal. Seasonal milk production was calculated according to the seasonal average milk yield of the herd, which depends on feeding practices and genetic improvement.

\subsubsection{Herd demography}

Herd demography depends on fertility parameters but also on the farmers' decisions concerning animal stocking or destocking. It was assumed that heifers become productive at 24 months and the average regional rate of fertility is about $0.83 \%$ [26]. The culling rate reflects the farmer's strategy in terms of renewal and performance, and was determined according to field observations [26].

\subsubsection{Interaction between bio technical and socio-economic components}

Feeding and livestock management involves short-term decisions (e.g. dairy productivity target and concentrate supplementation) as well as long-term decisions (e.g. equipment, buildings).

The farm cash depends on the expenditure for feed resources, charges relative to the fodder system, and on operational means (e.g., fuel, oil). All of these are proportional to the size of the farm and depend on the technical choices and the expected milk production. To cover current charges, farmers could use their own funds or ask for a short-term loan. The only constraint in the model was that the short-term credits could not exceed $20 \%$ of the seasonal sale of animal and crop products (plus received public subsidies). 
Table II. Deviation between the observed data and the simulation for the base year (2000) (in \%).

\begin{tabular}{lccccccc}
\hline & \multicolumn{3}{c}{ Characteristics } & \multicolumn{3}{c}{ Comparison between observed data and simulation (\%) } \\
\cline { 2 - 7 } & $\begin{array}{c}\text { Fodder area } \\
\text { (ha) }\end{array}$ & $\begin{array}{c}\text { Dairy cows } \\
\text { (number) }\end{array}$ & $\begin{array}{c}\text { Concentrates } \\
\text { supplied }\end{array}$ & $\begin{array}{c}\text { Milk } \\
\text { production }\end{array}$ & $\begin{array}{c}\text { Dairy cows } \\
\text { number }\end{array}$ & $\begin{array}{c}\text { Debt } \\
\text { due }\end{array}$ & $\begin{array}{c}\text { Disposable } \\
\text { Income }\end{array}$ \\
\hline Farm 1 & 6 & 24 & 6258 & -0.62 & -1.44 & 6.26 & 1.27 \\
Farm 2 & 24 & 57 & 7604 & 1.19 & 0.83 & -2.52 & 0.31 \\
Farm 3 & 14 & 48 & 7003 & -2.23 & 0.59 & -0.48 & 14.02 \\
Farm 4 & 3 & 20 & 7093 & 1.32 & 1.96 & 11.72 & 18.39 \\
Farm 5 & 6 & 19 & 4960 & -2.03 & -0.34 & 2.78 & -2.93 \\
Farm 6 & 22 & 25 & 6270 & -3.71 & -2.95 & 1.17 & -10.64 \\
\hline
\end{tabular}

Source: models results.

Investment decisions included farm buildings, farm equipment, land transactions and purchase of breeding stock. These investments depended on the farmers' projects and subsidies (premium or support) expectations, which are directly related to the animal population.

\subsubsection{Calibration and validation of the model}

According to Hazell and Norton [16], calibration in modelling is based on the determination of real parameter settings specific to each farm type, and validation assumes that the model reflects the base year situation (i.e., to check that the model reproduces the real activities and bio-economic conditions observed). The risk aversion coefficient $(\Phi)$ allows to differentiate between decisions in certain and in uncertain environments, and intervenes in the validation [24]. In our study, the parameters selected for calibration were defined from the observations of real practices and expert knowledge of the CIRAD-Pôle Élevage (cf. Appendix 1). Key variables for the validation were identified with dairy cooperative experts and farmers to understand the gaps between the reality and the model and to adjust the coefficients. The year 2000 was selected as a base year for this study.

Table II illustrates the deviation between the observed data and the simulation for the year 2000. It shows a relative correct approach of the real decision-making process of farmers, for both the bio-technical management and the economic results. The difference in disposable income between the simulation and reality results partly from the use of different methods to evaluate stores and depreciation investment. The depreciation rates used in the model are based on the expected duration of the investment, and not on fiscal rules, which can be to the advantage or disadvantage of the farmers.

\section{RESULTS AND DISCUSSION}

\subsection{Benchmarking and construction of the reference scenario}

Benchmarking is a simulation analysis performed under the assumption that policies/technologies remained unchanged until 2004. It involves analysing the model results for the planning horizon (2000-2004) without any external change. Benchmarking was aimed at achieving three goals: (i) to make sure that the model does not induce endogenous shocks; (ii) to confront at each farm group level the technical and economic results with the professional forecasting; and (iii) to construct a plausible reference scenario, essential to identify the change induced by exogenous shocks in the scenario analysis. 
In the reference scenario (benchmark), the model shows a gradual increase in milk production and cow number, over the simulation period of five years and for every group (Fig. 3). This was due to the re-establishment of the Dairy Development Plan, a local public support plan to the dairy sector. It can cover up to $75 \%$ of the price of pregnant heifers, if purchased on the island from the dairy cooperative (SICAlait), and 67\% if they are imported. Such a subsidy allows the smallest farmers (groups 1, 4, 5 and 6) to achieve the optimal number of dairy cows stated by SICAlait in their farm investment planning. The price support on milk maintains the viability and durability of dairy systems by increasing flexibility (adaptability) and the supply of cash.

The increase in the number of dairy animals was the most important in group 4 (around 19\%), although the number of dairy cows in groups 1 and 6 hardly ever went up to 35 . Due to the harsh environment, some of the pastures were difficult to cultivate in these groups. Therefore, to ensure a slight increase in dairy cattle, these farmers preferred to give green forage to animals and continue the purchase of concentrates. The proportion of concentrate in the animal feed ranged from 48 to $56 \%$ of the dry matter content.

The increased rate of dairy animals was less important for group 5, where the lack of available land led to a remaining dairy population steady around 30 dairy cows: with only 6 ha, mainly on the Plaine des Cafres, the farmers preferred to invest in high-yielding dairy cows. For the planning horizon, $47 \%$ of the dairy cows of this farm type produced around 6000 litres per year, vs. an average of 5500 litres per year in 2000. The farmers benefitted from subsidies for converting the pastures with temperate Gramineae into tropical grass (chloris), and on renewing a part of the fodder sugarcane area and green chloris, since only the feed during the dry season meets the animals requirements.

The dairy population increased in the largest farms, with a rate of $8 \%$ and $5 \%$ in groups 2 and 3, respectively. Group 2 farmers began their activity in the nineteeneighties, and they now intend to ensure the survival of two households by doubling the herd size, with an objective of 40 dairy cows per household. For the planning horizon, they will maintain this size and invest in new high-yielding dairy cows, which may be selected on the farm or bought abroad.

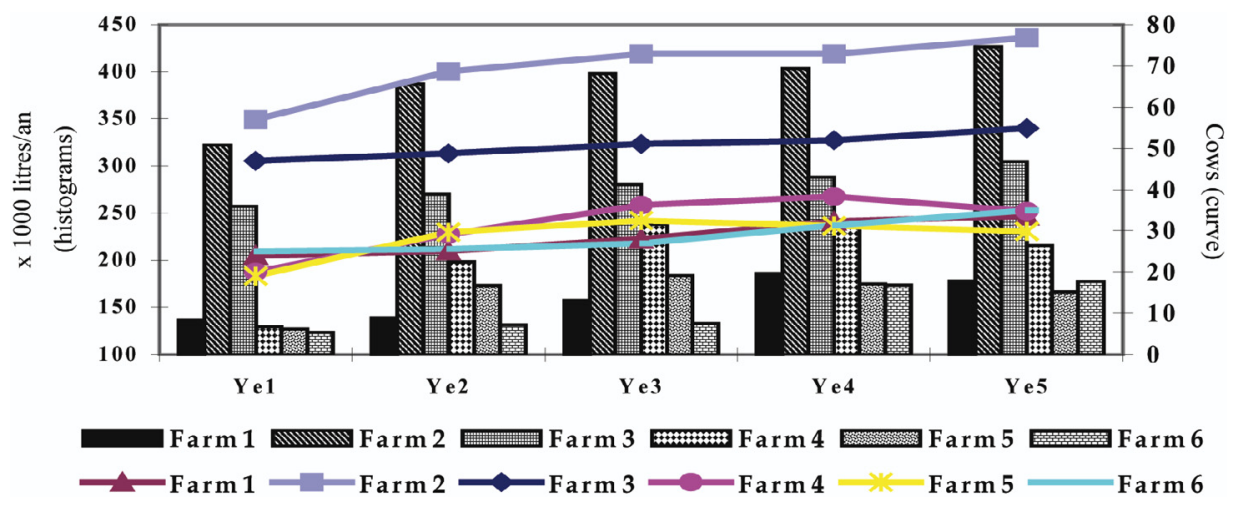

Source: models results

Figure 3. Trend of milk production and cows number of the 6 farm types in benchmarking. 


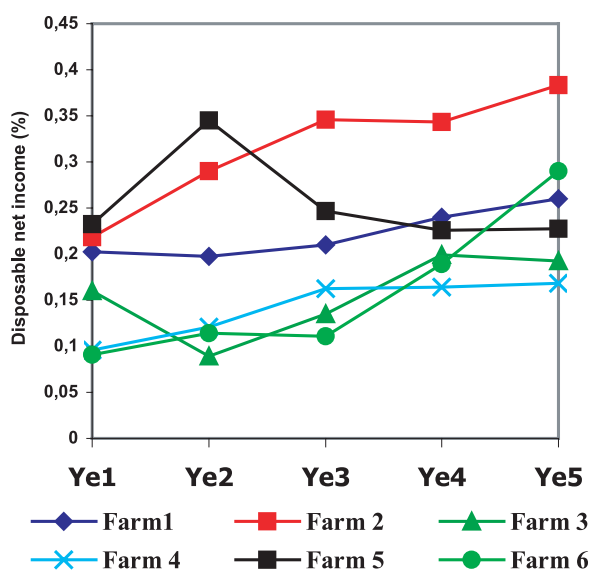

Source: models results

Figure 4. Trend of disposable net income.

In contrast, group 3 was comprised of young farmers who benefitted from incentives to build up their dairy cattle herds. The rapid increase in animal numbers entails longterm debts due to the important investments in buildings, machines, etc. Two phases of animal feed adjustment were noted for this group: (i) the increase in concentrates and the renewal of kikuyu pastures into temperate pastures during the first two years, and (ii) the increase of the silage part in the feed ration from the third year onward.

These results indicate that some farmers have to change pasture management to ensure that the nutritional requirements of the animals are met. Such an adaptation is not linear, and requires progressive phases of pasture renewal with adjustments based on concentrate level in the diet. They also allowed recalling the behaviour and objectives observed for each farm type: it is noted as an example that apart from groups 1 and 3 , all groups wished to convert part of their dairy herd into high-yielding dairy cows. Group 3 preferred to maintain and to stabilise its dairy productivity, and group 1 was very sensitive to maintaining its financial stability.

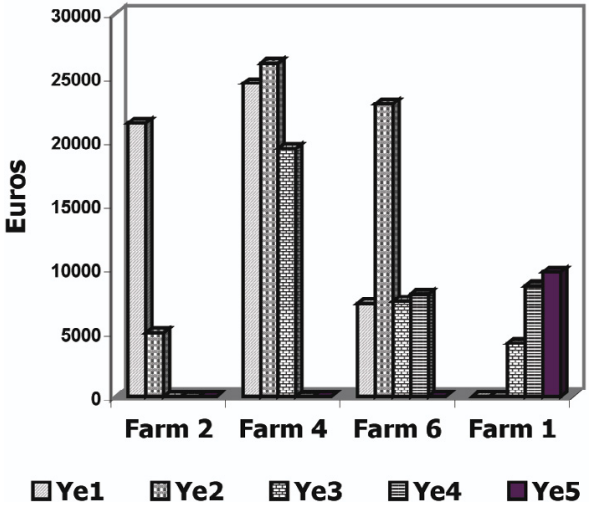

Figure 5. Trend of total debt for each farm type.

An increase in livestock assets and milk production could induce changes in the disposable net income and in debt levels. The analysis of disposable net income revealed a progressive increase in welfare in the oldest farms (groups 1, 2 and 4) due to the increase in livestock investments and in animal productivity. A slight increase in income was observed in group 3, but it was accompanied by a large variation over various years (Fig. 4), which was due to erratic fluctuations (group 5) or to the end of public support (group 3). The trebling of income in group 6 can be partly explained by catastrophic results in 2000 , due to the death of four dairy cows following an excess of concentrates. The increase in net disposable income also depends on the short (group 4) and long-term credits (group 6). In contrast, for groups 1 and 2, this growth did not disrupt financial stability. In addition, for groups 3 and 5, the low increase of the debt may be explained by the weight of the past long-term credit that limited the access to new credit and induced important annuity and low economic results (Fig. 5).

\subsection{Example of scenario analysis}

The scenario analysis consists of detecting the reaction of endogenous variables of 


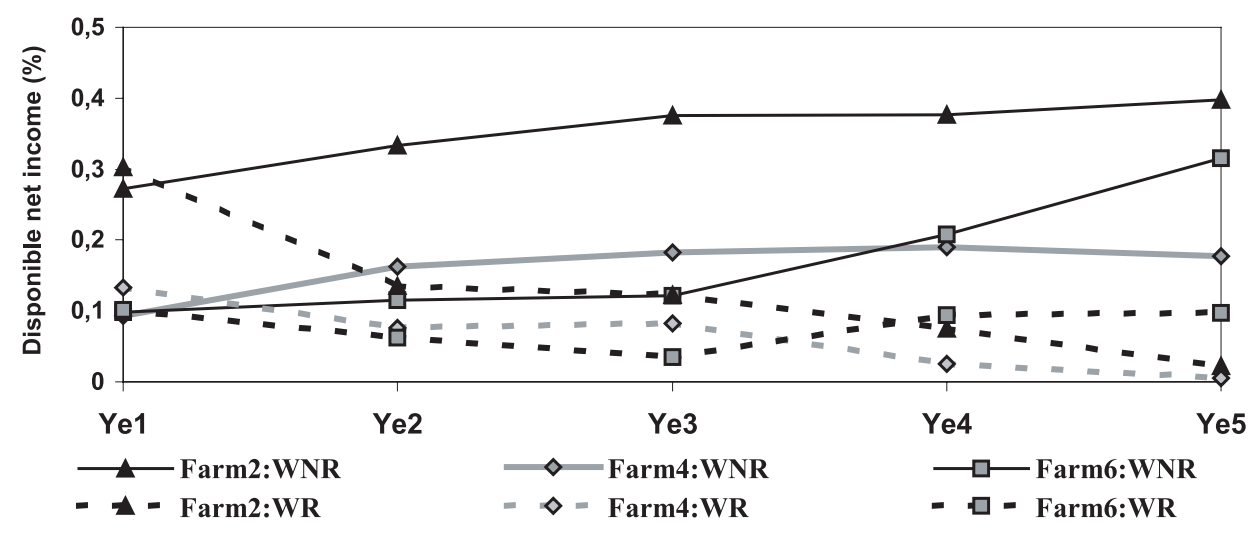

Source: models results

Figure 6. Trend of disposable net income with (WR) and without (WNR) elimination of price support.

the model to the various changes in exogenous parameters, such as prices, policy instruments, technologies. The aim of this analysis was to study the impact of different assumptions, relating to these parameters, on the model outcome and behaviour. The results of each scenario analysis will be compared to those of the reference scenario, in order to isolate the economic effects of the exogenous change introduced in the scenario.

In our study, the two goals of the scenario analysis were to show the type of simulation that can be done with the model, and to analyse the extreme sensitivity of most farming incomes to agricultural policies, with a particular focus on local government support. According to the reference scenario results (benchmarking), the difference between farms in structural and economic terms, as well as in the financial and technical strategies, would lead to diverse reactions and different adaptative behaviours under exogenous shocks (agricultural policy, introduction of innovation). The adaptation capacity of each group, especially to harsh conditions, seems to be very specific, although the simulation was done on the basis of a total specialisation in the dairy activity in all the farm groups. For instance, the impact analysis of the elimination of milk price support showed a drop in dairy production and disposable incomes shown on all farms, but at various rates depending on the degree of technical, financial and economic flexibility.

Figure 6 shows the trend of disposable income, with and without the elimination of price support. It shows the extreme sensitiveness of most farm incomes to price support. It also illustrates that the groups affected most would be large farms (farm 2), which have a high rate of debt and which ensure the renewal of one part of their herd, and group 4, which has a high level of production and financial costs (farm 4).

In terms of animal husbandry and production practices, this reform would be accompanied by various strategical and tactical decisions: (i) the reduction of the livestock number and intensification of fodder production for the large farms (farm 2), as well as for the farms which are based on grazing systems with low productivity (farm 6); (ii) a slight increase in the livestock number in group 4 (farm 4), to compensate for the high operational costs induced by short-term credit; (iii) although no change 
(the same trend) could occur in groups 1 and 5 , due to financial and economic stability.

Although these results show significant tendencies for the different dairy farming systems, they must be interpreted with caution according to the assumptions retained and to the choices made by the models.

\section{CONCLUSION}

The main results of this study confirmed a relatively good representation of reality by the model, in particular the investment decisions in livestock considering financial constraints, public support and individual management. This was made possible due to risk attitude assessment, and also because the past financial decisions, such as debt, were considered. The approach of the interrelations between biotechnical and socioeconomic components in the model well reflected the complexity of the decisionmaking process and the articulation between short- and long-term decisions. In addition, the multiplicity and diversity of data collected from scientists and grassland experts allowed a representation of the biotechnical management based on real practices.

Therefore, the model may be of great interest to understand the multiple and complex relationships between all components, and may evaluate the impact of external changes on the viability and sustainability of different dairy farm systems on the Réunion Island.

This modelling approach also appears to be an efficient way to combine multidisciplinary data of farm activities, as well as to create close relationships between economists, animal scientists and extension services. The modular structure permits linking additional economic and technical modules and facilitates the inclusion of new scientific knowledge. These models are currently operational and may be used, as a decision support tool, to help decision-makers, such as dairy cooperative leaders in considering management strategies of farms.

\section{ACKNOWLEDGEMENTS}

The present study has been conducted on the Réunion Island with the animal scientists at the Pôle Élevage, and with the expert technicians from the Dairy Cooperative (SICAlait) and other development agencies. We thank particularly Mr. Evenat (Director), Mr. Fertil, Mr. Lepetit and Mr. Bigot (technicians) from the Dairy cooperative, Dr. Choisis and Dr. Tillard, researchers at the Pôle Élevage, and Mr. Thomas and Mr. Barbet-Massin, technicians of UAFP, for their permanent support, collaborations and suggestions.

\section{REFERENCES}

[1] Alary V., Boussard J.M., Actualisation, risque, cacao - Sur les insuffisances de la théorie, Econ. Rurale 259 (2000) 64-74.

[2] Alary V., Messad S., Tillard E., Approche fonctionnelle de la diversité des systèmes d'élevage laitiers à l'Ile de La Réunion. Utilisation de l'AFM (Analyse Factorielle Multiple) comme aide à l'interprétation de la variabilité inter et intra groupe, Renc. Rech. Rumin. 8 (2001) 251-255.

[2bis] Alary V., Deybe D., Price policies and agricultural supply - The responses of producers in Haryana (India), in: Tomorrow's agriculture: incentives, institutions, infrastructure and innovations, XXIV International Conference of the International Association of Agricultural Economists, Berlin, Germany, August 2000, 12 p.

[3] Arfini F., The effects of CAP reform on two Italian regions: a positive mathematical programming application, in: Ottone Ferro (Ed.), What future for the CAP? Perspectives and expectations for the CAP of the European Union, 1996, pp. 103-109.

[4] Arfini F., Mathematical programming models employed in the analysis of the Common Agricultural Policy, Working Paper, INEA, Italy, 2001, p. 35.

[5] Barbier B., Bergeron G., Impact of policy interventions on land management in Hondouras: results of a bio-economic model, Agric. Syst. 60 (1999) 1-16.

[6] Barkaoui A., Butault J.P., Modélisation de l'agriculture meusienne et Paquet Santer, Econ. Rurale 248 (1998) 13-20. 
[7] Blanfort V., Thomas P., Fontaine O., Rivière E., La gestion agroécologique des prairies, in: Mandret G. (Ed.), L'élevage bovin à La Réunion - Synthèse de quinze ans de recherche, CIRAD/INRA/CAH/Région Réunion, Coll. Repères, 2000, pp. 129-160.

[8] Boussard J.M., Économie de l'agriculture, Economica, Paris, 1988, 320 p.

[9] Boussemart J.Ph., Jacquet F., Flichman G., Lefer H.B., Prédire les effets de la réforme de la PAC sur deux régions agricoles françaises : application d'un modèle bio-économique, Rev. Can. Econ. Rurale 44 (1996) 121 138.

[10] De Benedictis M., Cosentino V., Economia dell'azienda agraria, I1 Mulino, Bologna, 1979.

[11] Deybe D., Can Agricultural Sector Models be a Tool for Policy Analysis? An Application for the case of Burkina Faso, Agric. Syst. 58 (1998) 367-380

[12] Flichman G., Bio-economic models integrating agronomic, environmental and economic issues with agricultural use of water, Opt. Méditerr. 31(1997) 327-336.

[13] Gohin A., Chantreuil F., La programmation mathématique positive dans les modèles d'exploitation agricole, Cah. Écon. Sociol. Rurales 52 (1999) 60-79.

[14] Grimaud P., Thomas P., Diversité des rations à base de graminées et gestion des prairies en élevage bovin sur l'île de la Réunion, Fourrages 169 (2002) 65-78.

[15] Hassoun P., Paillat J.M., Mandret G., Brunschwig P., Bigot A., Latchimy J.Y., Les rations en élevage laitier, in: Mandret G. (Ed.), L'élevage bovin à La Réunion - Synthèse de quinze ans de recherche, CIRAD/ INRA/CAH/Région Réunion, Coll. Repères, 2000, pp. 225-248.

[16] Hazell P., Norton R.D., Mathematical Programming for economic analysis in agriculture, MacMillan, London, 1986, 400 p.
[17] Heckelei T., Positive mathematical programming: Review of the standard approach, CAPRI Working paper, University of Bonn, 1997.

[18] Howitt R.E., Positive mathematical programming, Am. J. Agric. Econ. 77 (1995) 329342.

[19] Jacquet F., Le risque dans le modèle d'exploitation agricole, Montpellier, CIHEAM-IAMM, 2000, p. 12.

[20] Louhichi K., Essai de modélisation bio-économique de la relation agriculture-environnement : le cas de l'érosion en Tunisie, Thèse de doctorat en sciences économiques, Université de Montpellier I, 2001, 250 p.

[21] Louhichi K., Fertil G., Alary V., Choisis J.P., Lepetit J., Apport de la modélisation économique à l'analyse prospective et l'aide au pilotage des systèmes d'élevage laitier à $\mathrm{La}$ Réunion, Renc. Rech. Rumin. 9 (2002) 57 60.

[22] McCarl B.A., Cropping activities in agricultural sector models: a methodological proposal, Am. J. Agric. Econ. 64 (1982) 768 771.

[23] Paris Q., Howitt R.E., An anlyse of III-posed production problems using maximing entropy, Am. J. Agric. Econ. 80 (1998) 124-138.

[24] Roumasset J., Boussard J.M., Singh I., Risk, uncertainty and agricultural development, Agricultural Development Council, NewYork, USA, SEARCA (Ed.), 1979, 454 p.

[25] Tauer L.W., Target MOTAD, Am. J. Agric. Econ. 65 (1983) 606-610.

[26] Tillard E., Lanot F., Bigot C.-E., Nabeneza S., Pelot J., Les performances de reproduction en élevage laitier, in: Mandret G. (Ed.), L'élevage bovin à La Réunion - Synthèse de quinze ans de recherche, CIRAD/INRA/ CAH/Région Réunion, Coll. Repères, 2000, pp. 257-292. 


\section{Appendix 1. Example of technical-economic coefficients included in the model.}

Table A1. Average technical-economic coefficients for fodders.

\begin{tabular}{|c|c|c|c|c|c|c|c|c|}
\hline & & & $\begin{array}{l}\text { Cutting } \\
\text { number }\end{array}$ & $\begin{array}{c}\text { Maintenance } \\
\text { cost } \\
\end{array}$ & \begin{tabular}{|c|}
$\begin{array}{c}\text { Transport }+ \\
\text { cut costs }\end{array}$ \\
\end{tabular} & $\begin{array}{l}\text { Total } \\
\text { costs } \\
\end{array}$ & Yield & $\begin{array}{l}\text { Feed } \\
\text { Unit }\end{array}$ \\
\hline Fodder & Species & Season & & (Euro/ha) & \begin{tabular}{|l|} 
(Euro/ha) \\
\end{tabular} & (Euro/ha) & (TDM/ha) & $(/ \mathrm{kgDM})$ \\
\hline \multirow{12}{*}{$\begin{array}{l}\text { Pennisetum } \\
\text { clandestinum } \\
\text { (Kikuyu) }\end{array}$} & \multirow{6}{*}{ Green } & \multirow{3}{*}{ Summer } & 1 & 492 & 106 & 598 & 9.00 & 0.31 \\
\hline & & & 2 & 770 & 116 & 886 & 8.84 & 0.57 \\
\hline & & & 3 & 1047 & 127 & 1174 & 7.95 & 0.65 \\
\hline & & \multirow{3}{*}{ Winter } & 1 & 211 & 65 & 276 & 5.50 & 0.35 \\
\hline & & & 2 & 422 & 71 & 493 & 5.42 & 0.65 \\
\hline & & & 3 & 633 & 78 & 711 & 4.86 & 0.74 \\
\hline & \multirow{6}{*}{ Silage } & \multirow{3}{*}{ Summer } & 1 & 492 & 134 & 626 & 10.00 & 0.31 \\
\hline & & & 2 & 770 & 150 & 920 & 10.00 & 0.62 \\
\hline & & & 3 & 1047 & 182 & 1229 & 10.00 & 0.72 \\
\hline & & \multirow{3}{*}{ Winter } & 1 & 211 & 124 & 335 & 9.24 & 0.35 \\
\hline & & & 2 & 422 & 139 & 561 & 9.24 & 0.62 \\
\hline & & & 3 & 633 & 168 & 801 & 9.24 & 0.72 \\
\hline \multirow{12}{*}{$\begin{array}{l}\text { Lolium } \\
\text { perenne } \\
\text { (Ray grass) }\end{array}$} & \multirow{6}{*}{ Green } & \multirow{3}{*}{ Summer } & 1 & 492 & 149 & 640 & 12.60 & 0.50 \\
\hline & & & 2 & 770 & 157 & 927 & 11.94 & 0.70 \\
\hline & & & 3 & 1047 & 176 & 1224 & 11.05 & 0.74 \\
\hline & & \multirow{3}{*}{ Winter } & 1 & 211 & 53 & 264 & 4.50 & 0.55 \\
\hline & & & 2 & 422 & 58 & 480 & 4.42 & 0.79 \\
\hline & & & 3 & 633 & 62 & 695 & 3.86 & 0.83 \\
\hline & \multirow{6}{*}{ Silage } & \multirow{3}{*}{ Summer } & 1 & 492 & 134 & 626 & 10.00 & 0.50 \\
\hline & & & 2 & 770 & 150 & 920 & 10.00 & 0.67 \\
\hline & & & 3 & 1047 & 182 & 1229 & 10.00 & 0.78 \\
\hline & & \multirow{3}{*}{ Winter } & 1 & 211 & 124 & 335 & 9.24 & 0.55 \\
\hline & & & 2 & 422 & 139 & 561 & 9.24 & 0.67 \\
\hline & & & 3 & 633 & 168 & 801 & 9.24 & 0.78 \\
\hline \multirow{12}{*}{$\begin{array}{l}\text { Pennisetum } \\
\text { purpureum } \\
\text { (Mixte) }\end{array}$} & \multirow{6}{*}{ Green } & \multirow{3}{*}{ Summer } & 1 & 492 & 137 & 629 & 11.65 & 0.45 \\
\hline & & & 2 & 770 & 137 & 906 & 10.39 & 0.65 \\
\hline & & & 3 & 1047 & 152 & 1199 & 9.50 & 0.69 \\
\hline & & \multirow{3}{*}{ Winter } & 1 & 211 & 65 & 276 & 5.50 & 0.50 \\
\hline & & & 2 & 422 & 65 & 487 & 4.92 & 0.70 \\
\hline & & & 3 & 633 & 70 & 703 & 4.36 & 0.78 \\
\hline & \multirow{6}{*}{ Silage } & \multirow{3}{*}{ Summer } & 1 & 492 & 134 & 626 & 10.00 & 0.45 \\
\hline & & & 2 & 770 & 150 & 920 & 10.00 & 0.67 \\
\hline & & & 3 & 1047 & 182 & 1229 & 10.00 & 0.77 \\
\hline & & \multirow{3}{*}{ Winter } & 1 & 211 & 124 & 335 & 9.24 & 0.50 \\
\hline & & & 2 & 422 & 139 & 561 & 9.24 & 0.67 \\
\hline & & & 3 & 633 & 168 & 801 & 9.24 & 0.77 \\
\hline \multirow{6}{*}{$\begin{array}{l}\text { Fodder } \\
\text { cane } \\
\text { for animals }\end{array}$} & \multirow{6}{*}{ Green } & & 1 & 252 & 74 & 326 & 12.60 & 0.35 \\
\hline & & Summer & 2 & 448 & 79 & 527 & 11.94 & 0.67 \\
\hline & & & 3 & 645 & 88 & 733 & 11.05 & 0.78 \\
\hline & & & 1 & 226 & 26 & 253 & 4.50 & 0.35 \\
\hline & & Winter & 2 & 452 & 29 & 482 & 4.42 & 0.67 \\
\hline & & & 3 & 679 & 31 & 709 & 3.86 & 0.78 \\
\hline
\end{tabular}


Table A2. Average technical-economic coefficients for fodders (continuation).

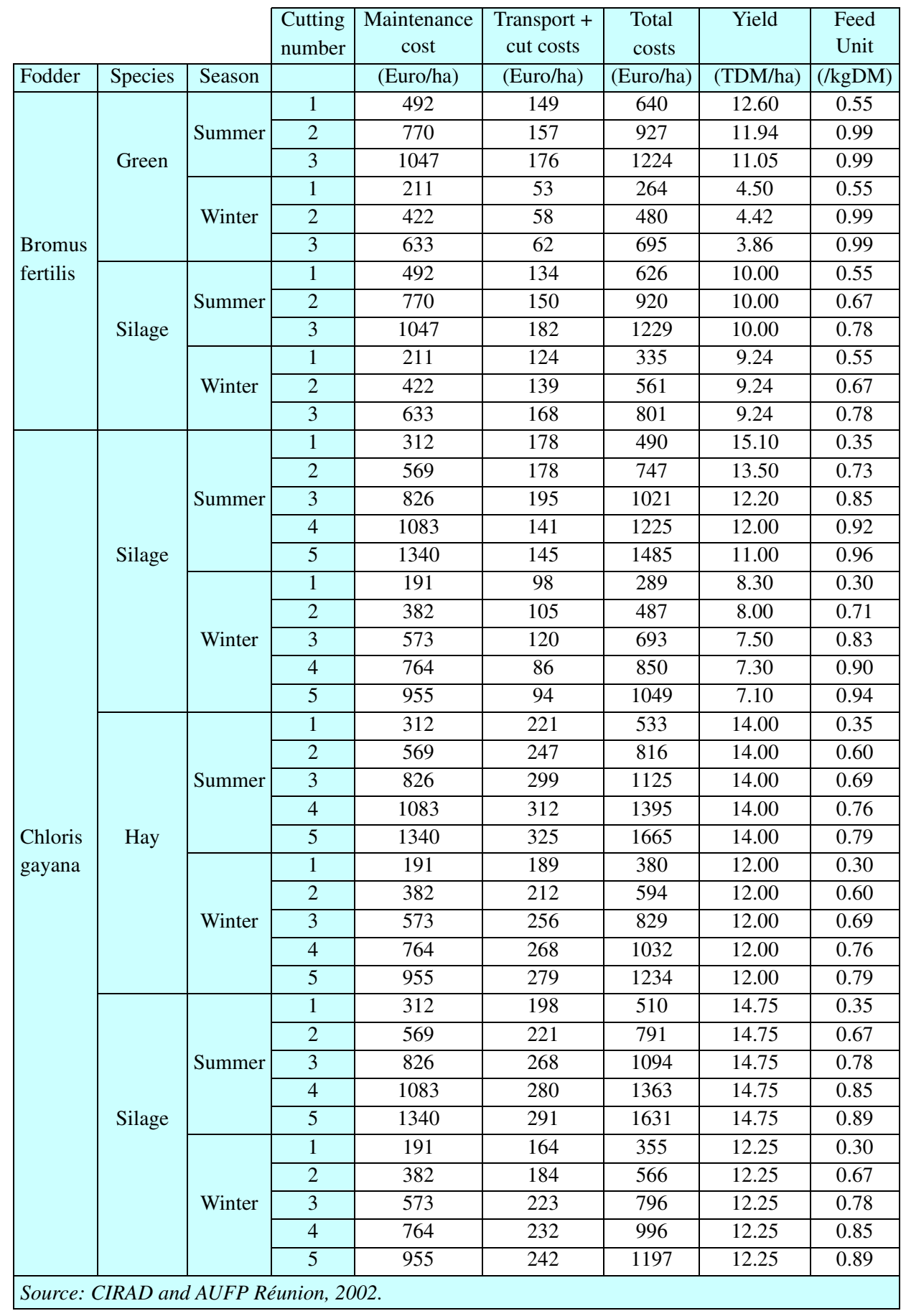




\section{Appendix 2. Principal equations of the model}

\section{Sets}

C: Crop, fodder and grassland species

Ame: Land operation development

T: Technique

P: Harvesting system

Pfau: Harvesting system by cutting

Ppat: Harvesting system by grazing

CP: Number of cuttings and grazing during the season

G: geographical area

F: farm type

TBOV: Animal categories

GEN: Real genetic potential

PC: Season

Ye: Year

\section{The objective function}

Max: $\mathrm{U}=\sum_{y e=t 0}^{T} \frac{Z_{y e}-\phi \lambda_{t}}{(1+\tau)^{y e}}$

with $\mathrm{Z}_{\mathrm{ye}}$ : expected disposable net income

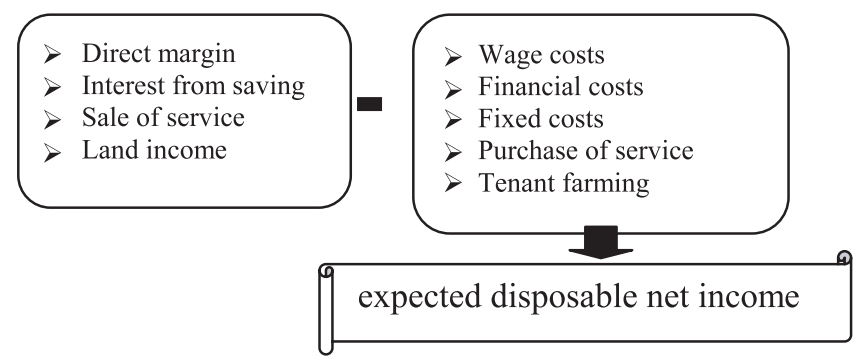

\section{The main constraints}

\section{Land management and forage characteristics}

For each farm type (f) located in one geographical area (g), the total cultivated land (TLABOU) during one season (pc) of the year (ye) is described by the following equation:

(1)

$$
\text { TLaboug, }, \text { pc,ye }_{c}=\sum_{c, c p, a m e, p, t} T E R C_{g, f, c, c p, a m e, p, t, p c, y e}
$$


TERC is divided into different pastures according to land accessibility for mechanisation (fitted to reap or no (ame)), the renewal or no (t), the grass species (c), the harvesting system (p), and the number of cutting (cp). So, the fodder resources in tones (RECOLT) are calculated as:

2

$$
\operatorname{RECOLT}_{g, f, c, c p, p f a u, p c, y e}=\sum_{t} T E R C_{g, f, c, c p, ' f a u c h ', p f a u, t, p c, y e} * Y I E L D_{g, c, c p, p f a u, t, p c}
$$

YIELD (exogenous parameter) is the seasonal yield for each species according to the pasture renewal decisions $(\mathrm{t})$ during the season, the location $(\mathrm{g})$, the harvesting system (pfau) and number of cuttings. The production can be consumed (CONST), stocked (STOCKEND) or sold (SOLD) to the market. The total consumption of fodder resources is based on the past stock (STOCKINI), the new stock and the purchases $(A C H A T)$. So, the new stock is written as:

\section{$3 \quad S T O C K E N D_{g, f, c, c p, p f a u, p c, y e}=S T O C K I N I_{g, f, c, c p, p f a u, p c, y e}+R E C O L T_{g, f, c, c p, p f a u, p c, y e}$

$$
-C O N S T_{g, f, c, c p, p f a u, p c, y e}+A C H A T_{g, f, c, c p, p f a u, p c, y e}-S O L D P_{g, f, c, c p, p f a u, p c, y e}
$$

The total diet (except concentrates) comprises produced and purchased feed. Fodder availability on the island is a real constraint for all the farmers due to land pressure and harsh environment. The main available resources are the sugarcane by-products (bagasse, cabbage, straw), but these resources are limited to mechanised sugarcane plantations. To simplify, a regional seasonal availability of forage assumed according to cooperative's assessment and farmers' management is supposed.

\section{Animal feeding}

FEED variable is the quantity of nutrient content (nut), in particular in dry matter, energy and protein for each type of conditioning (pfau) and for each season. Total nutrient intake is calculated as follows:

( $F E E D_{g, f, p f a u, n u t, p c, y e}=\sum_{c, c p} C O N S_{g, f, c, c p, p f a u, p c, y e} * V_{A L I M} M_{c, c p, p f a u, n u t, p c}$

Therefore, the nutritional contents of feed and concentrates in energy and protein (nut) must cover the herd requirements each season.

$2 \sum_{\text {Pfau }} F E E D_{g, f, p f a u, n u t, p c, y e}+\sum_{c o n} C O N C_{g, f, c o n, n u t, p c, y e} \geq \sum_{b o v, g e n}\left[B A S E_{b o v, g e n, n u t} * E F F_{g, f, b o v, g e n, p c, y e}\right]$

Gen reflects both the real genetic improvement and the feeding strategy of the farmer to increase milk productivity. BASE is the minimum daily diet (in line with the genetic potential and feeding strategy), multiplied by the number of days in the season.

A similar equation (6) reflects the ash requirements (ash) in calcium and phosphorus:

$3 \sum_{\text {Pfau }} F E E D_{g, f, p f a u, a s h, p c, y e}+\sum_{c o n} C O N C_{g, f, c o n, a s h, p c, y e} \geq \sum_{b o v, g e n}\left[B A S E_{b o v, g e n, a s h} * E F F_{g, f, b o v, g e n, p c, y e]}\right.$ 
Seasonal milk production (PRODMILK) is calculated with the seasonal average milk yield of the herd (YMilk), which depends on feeding practices and genetic improvement (gen). So, milk production is calculated as:

4

$$
\text { PRODMILK } K_{g, f, p c, y e}=\sum_{\text {vlait,gen }} K_{\text {Milkgen }} * E F F_{g, f \text { vlait,gen, pc,ye }}
$$

\section{Herd demography}

Figure A.1 reflects the demographic change at the herd level, between seasons in the same year and between years respectively. It also reflects the diverse possibilities concerning purchases, sales and stocks of animals.

Interaction between bio technical and socio-economic components

The cash flow is written as:

$$
\begin{aligned}
& \text { ( } C A S H_{g, f, p c, y e}=R E C E I P T_{g, f, p c, y e}-E X P E N D_{g, f, p c, y e}+\Delta S t o c k_{g, f, p c, y e}+C A S H_{g, f, p c-1, y e} \\
& +A N N U I_{g, f, p c, y e}+D E B T D U E_{g, f, p c, y e}+C R E D C T_{g, f, p c, y e}-R E M B U R_{g, f, p c, y e} \\
& -S A V E_{g, f, p c, y e}-C O N S_{g, f, p c, y e}-K I N V_{g, f, p c, y e}-F I X E_{g, f, p c, y e}
\end{aligned}
$$

The receipt (RECEIPT) comprises the sale of animal and vegetable products (mainly milk and forage), the financial support (as the subsidy or premiums from the Common Agricultural Policy CAP) but also salaries or incomes from other non agricultural activities; the expenditure (EXPEND) concerns all the operational charges such as fuel, fertiliser, purchased feed, labour, rent in. To these traditional transfers, the variation of stock, the annuity (ANNUI), the debt due (DEBTDUE), the contracted credit in the season (CREDCT) and the cash of the previous season (CASHpc-1) are added. After, the saving (SAVE), the fixed charge (FIXE), the private consumption (CONS) and the capital for investment (KINV) are calculated. Saving will increase the capital asset of the farm.

The investments in farm buildings (NewBUILD) are directly related to animal population and the minimum required building (UniBUILD). The nursery building and the dairy unit are distinguished in the set "bat". So, the capacity of actual building (BUILD) is written as:

2

$$
\begin{gathered}
\text { BUILD } D_{g, f, b a t, p c, y e}=\text { BUILD } D_{g, f, b a t, p c-1, y e}+\text { NewBUILD } D_{g, f, b a t, p c, y e} \\
\text { BUILD } D_{g, f, b a t, p c, y e} \geq \sum_{\text {ani,gen }} E F F_{g, f, a n i, g e n, p c, y e} * \text { UnitBuildani,bat }
\end{gathered}
$$

For the farm equipment (tractor, mower, silo filler, etc.) the farmers can rent in (RENTin) or rent out (RentOut) according to their needs (REQEQ), their own equipment 
(EQUIP) and their new investments (NewEquip). The requirement for cropping and livestock operations according to their management is expressed as:

3

$$
\begin{gathered}
\operatorname{REQEQ}_{g, f, e q, p c, y e} \geq \operatorname{EQUIP}_{g, f, e q, p c-1, y e}+\operatorname{NewEQUIP}_{g, f, e q, p c, y e} \\
+ \text { RENTin }_{g, f, e q, p c, y e}-\text { RENTout }_{g, e x, e q, p c, y e}
\end{gathered}
$$

These investments are covered with personal capital (KINV) and long-term credit (CREDLT).

4

$$
\sum_{I} \operatorname{INVEST}_{g, f, I, p c, y e}=K I N V_{g, f, p c, y e}+C R E D L T_{g, f, p c, y e}
$$

Where (I) is the type of investment. The sliding annuity is calculated each season and deducted from the cash flow. The sliding annuity cannot exceed $80 \%$ of the gross operating profit and the personal capital must cover at least $20 \%$ of the investment.

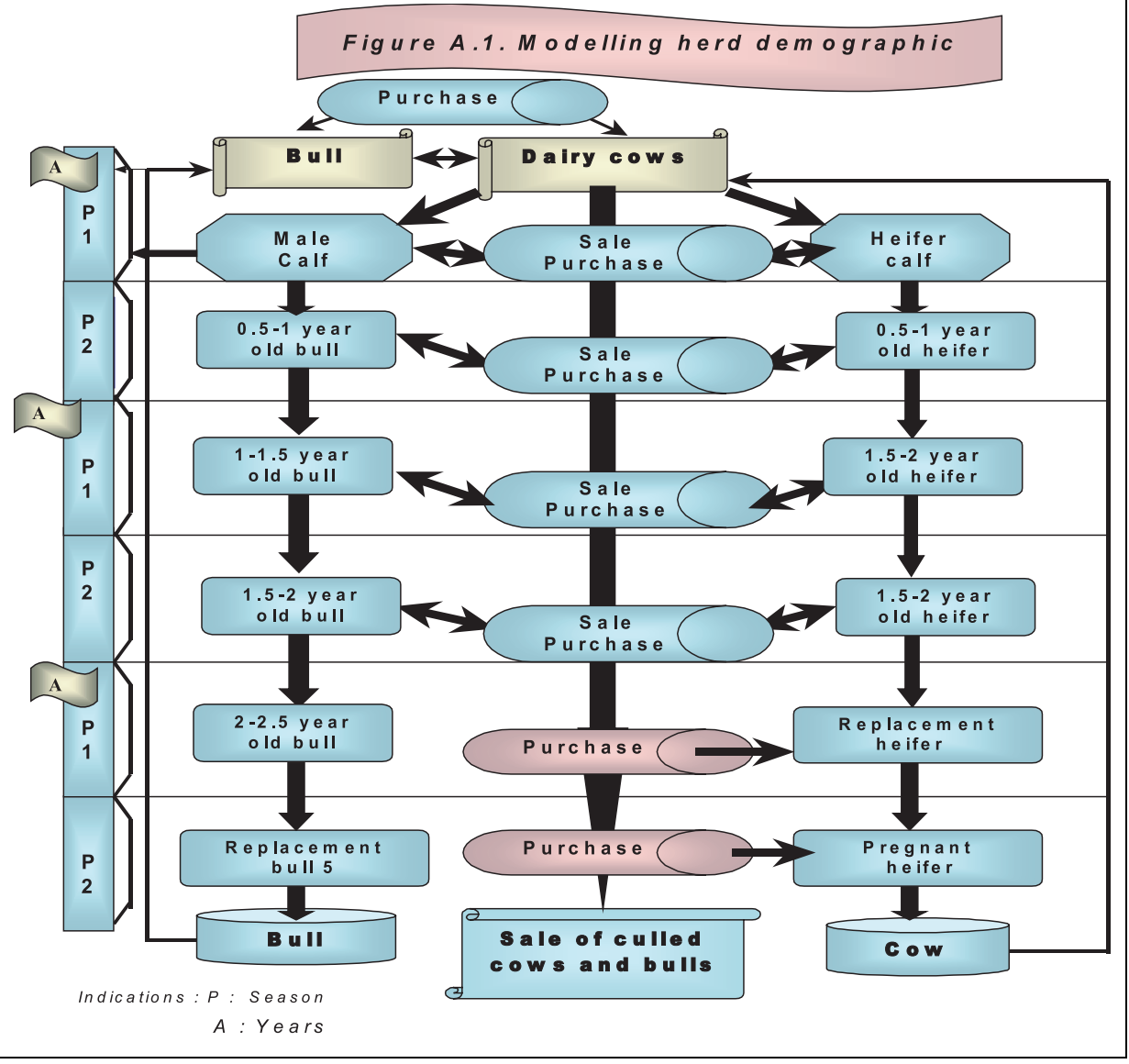

